Historic, Archive Document

Do not assume content reflects current scientific knowledge, policies, or practices. 



\section{$6+6) 6$}

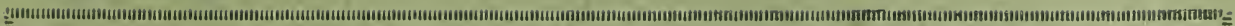

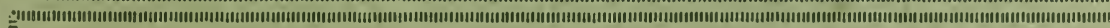
三

\section{NINETEEN TWENTY-NINE}

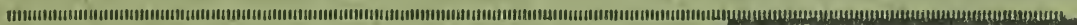

L IB F A F

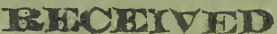

+ MAY 91929

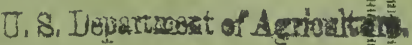
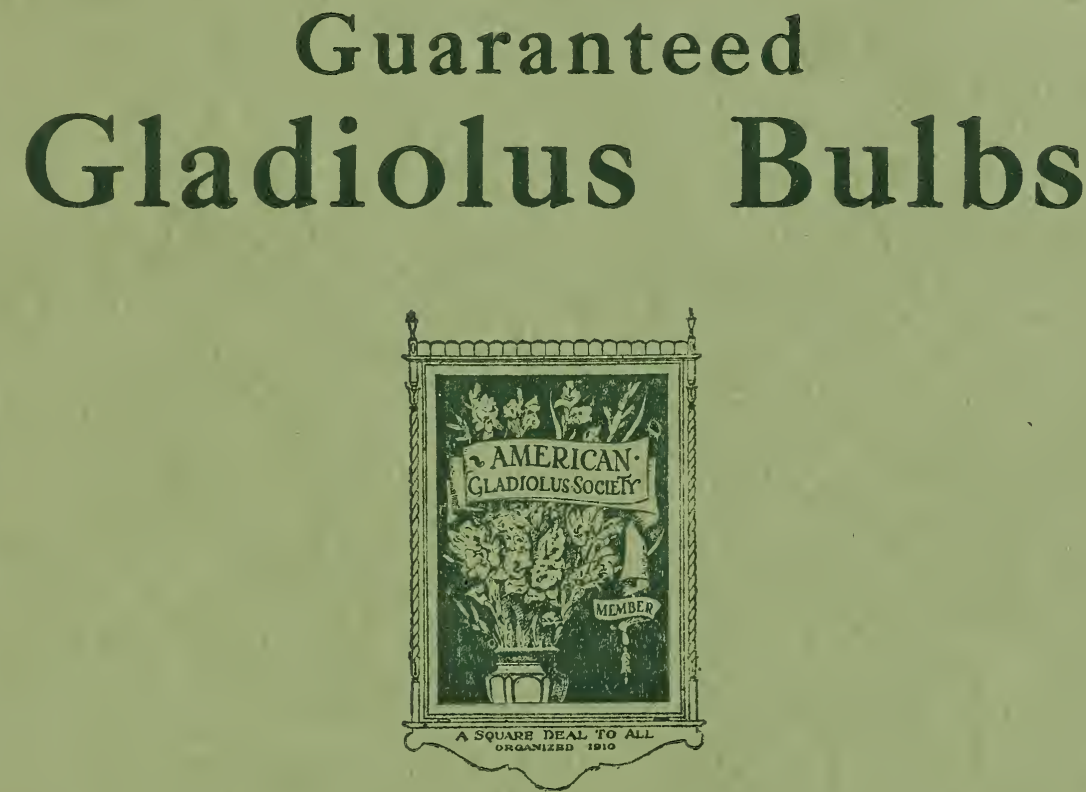

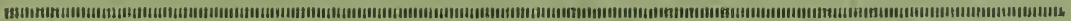

\section{Ashville Flower Fields}

Claude A. Carpenter, Prop. Ashville, New York 



\section{The Ashville Flower Fields}
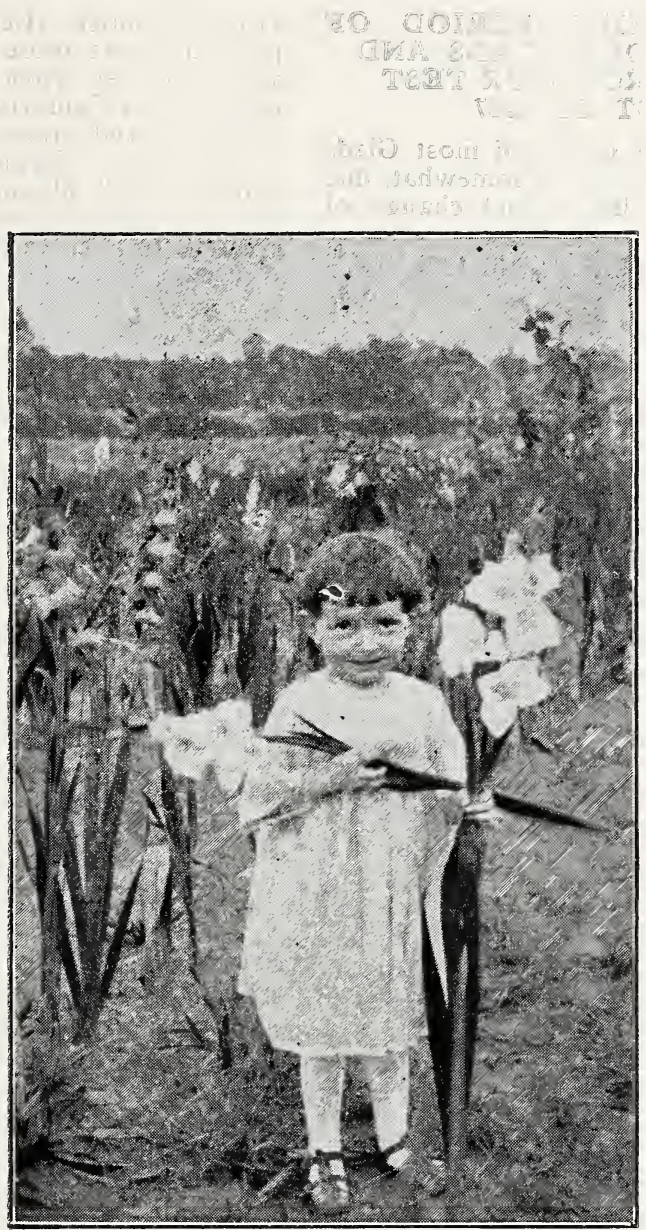

View of a part of Ashville Flower Fields Seedling Test Gardens. 


\section{THE BLOOMING PERIOD OF SOME OF OUR GLADS AND NOTES FROM OUR TEST PLOT OF 1927}

The blooming period of most Glads is not definite, it varies somewhat, due to climatic conditions and change of soil.

Our records show that in 1927 "Normanda" bloomed in 46 days after planting. This is the second time that it has bloomed before all others, but generally it develops along with "Prince of Wales" and sends up two or three spikes from a large bulb-the stronger coming on first and the others latercausing a row to bloom constantly until frost. They are always a very robust and healthy plant, sometimes growing over four feet high with spikes always straight. The flower stands the sun and rain exceptionally well thus making an ideal landscap ${ }^{\circ}$ variety.

"Lottie Belle", one of our earliest Glads, bloomed in 48 days and lasted until Prince of IVales and Le Marechal Foch began to bloom.

Last year we were surprised when a new seedling bloomed nearly a week earlier than the rest. This year it bloomed in 50 days, and is a Glad which we anticipate will speak for itself.

"Segrid Stein", another fine early seedling bloomed in 51 days. This is a cream white Glad, very attractive, and has demanded considerable attention in our test plot.

"Elizabeth Tabor" and our "Oneida Jane", both opened in 60 days.

"Lynda Day" and "Eva Martin" came along in 65 days, with "Marolee" in 66 days. This Glad is a little different than any I have ever seen. both in shape and color (see illustration) and has attracted much attention in our test plot. Then "Uani", one of the tallest seedlings we have, growing often over 6 feet tall, with very straight spike and bloom 6 inches across. This also bloomed in 66 days. Stock is yet too limited to catalogue for a couple of years.

It took "Ella Day" 73 days to produce a spike of bloom. We were unable to get a good picture of this for a cut this year as we were away when the hest ones were in bloom. This has attracted much attention in our test plot, and gets more than its share of attention even when planted alongside of "Pearl of California," "Mrs. Sisson," "Phipps," and others.

"Atalanta," "Sirene," "I Lois Mary," and "Onilee" bloom about the same time as "Evelyn Kirtland" and are very good cut flower varieties.

Then there is a long list of other seedlings that I can not mention here at this time. Two or three showed a tendency to send out extra spikes from just above the ground. One produced three spikes 20,16 and 12 buds. This was a very good one and I raised seed on the first two so they were not cut.

Come and see our Glads. They speak for themselves.

\section{NOTES FROM TRIAL PLOT FOR 1928}

Up until July the growing season of 1928 was a very poor one, but our Glads did much better than we expected.

Lottie Belle and Marolee, the first to bloom this year, came out in sixty days. Lottie Belle is the earliest real cut flower variety we have ever grown. We like it much better than many prettier Glads. It comes with an abundance of bloom just when we want it most, and when there is hardly any other variety out. The spikes are all straight, and a bunch of No. 1 bulbs will nearly all bloom within a week of one another.

Marolee is proving to be one of the earliest exhibition varieties. This is a wonderful large flower that should be in every collection. It is different from other Glads both in shape and color.

The first Normanda bloomed in 66 days and still proves its worth as a landscape variety by continuing to bloom until irost.

We have several other seedlings in the 60 -day class that will be heard from later.

Break O' Day bloomed in 73 days, Elizabeth Tabor in 74. Segrid Stein bloomed in 75 days, being later this year than common. This is a very fine early cut flower variety. The spike is always straight, and has about 


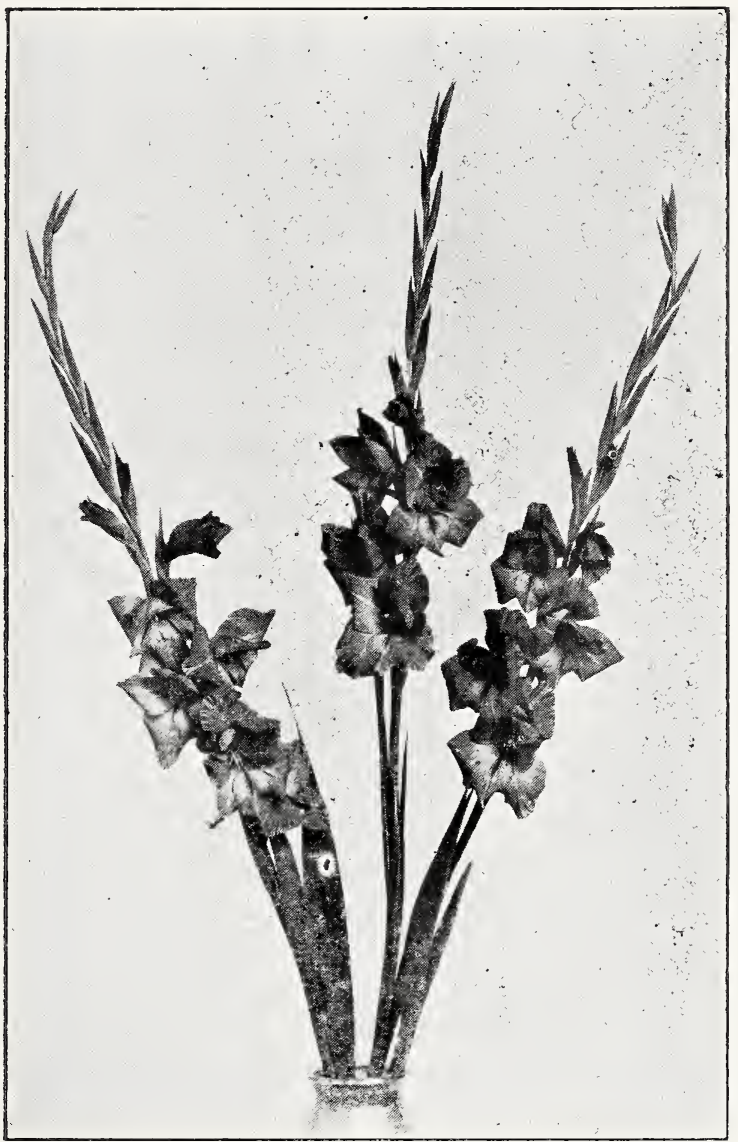

Flossie 
seven open at a time.

Flossie bloomed about the same time as Prince of Wales. If you have extra good soil this will be a wonder. We have seen it five feet tall, and bloom six inches across.

On some kinds of soil we find that Ella Day will fleck or grow with streaks like Leon Douglas, yet many of our visitors like it that way as well as when it comes clear. Even with this fault we like it still.

This year we are introducing seven new ones.

Fanny Crosby is a wonderful creamy white, with waxy texture. It produces a fine large spike of often over 20 buds, with 7 or 8 open at once. Thus far every spike has had several florets with 8 to 12 petals. For funeral work this color makes up far better than a pure white.

The color of Janice is about half way between Marmora and Emile Auburn. It is a Glad that shows up extra well under artificial lights.

Annie Mason is a very large white, colored about like Jorges White. This is a wonderful propagator and has a good long spike often growing about five feet high.

Bonniebelle, a good strong growing Glad, always attracts attention.

Ethel Mae and Rufus are cut flower varieties that are strong growers, and produce wonderfully fine bulbs.

In selecting these from the many in our trial plot we look for a Glad with bloom of good substance (with good shipping and keeping qualities), and good placement; and with straight spikes. They must produce good bulbs, as well as many bulblets that will grow.

Our prices are much less than those of many other originators, the quality of the Glads considered. We have tried many higher priced ones in our trial grounds, and judging from what our visitors say, they are no better.

Out of the many seedlings we have been growing in our trial grounds for our or five years we chose these seven: because they were good pro- pagators and healthy growers; and have good placement, and last but not least, good substance.

In our commercial display at Toledo Show we labeled several varieties by number. These we have not listed because we do not have sufficient stock of them, and because we have had them in our trial grounds for only one to three seasons, which we do not consider sufficient time to thoroughly test them. Ethel Mae was labeled "No. 80." If you are interested in any of those you saiv at the Toledo Show write us about them.

\section{OUR TERMS}

Prices are for cash with order. A $20 \%$ payment will hold an order for future delivery. All bulbs will be postpaid.

All offerings are subject to previous sale.

All descriptions are as accurate as we are able to write them. The description of our ORIGINATIONS are based on Ridgeway's Standard Color Chart.

\section{OUR GUARANTEE}

Our bulbs are all guaranteed to be true to name, and will be replaced free of charge if not found so. Errors may occur occasionally. Should this happen, notify us at once and correction will be promptly and cheerfully made. You are the judge.

All bulbs will be vigorous flowering size, $1 \frac{1}{4}$ inches or larger.

\section{ABOUT SIZES}

Commercially the gladiolus is divicle 1 into six sizes: No. 1 is over $11 / 2$ inches in diameter; No. 2 is $11 / 4-11 / 2$ : No. 3 is $1-1 \frac{1 / 4}{4}$; No. 4 is $3 / 4-1$; No. 5 is $1 / 2-3 / 4$; No. 6 is below $1 / 2$ inch. For retail trade Nos. 1 and 2 are called large by most growers and No. 3 and No. 4 medium. These are my sizes. But a few growers call No. 3 large and Nos. 4 and 5 medium. Such growers can make very low prices. Be sure what size the grower is offering for the money. 


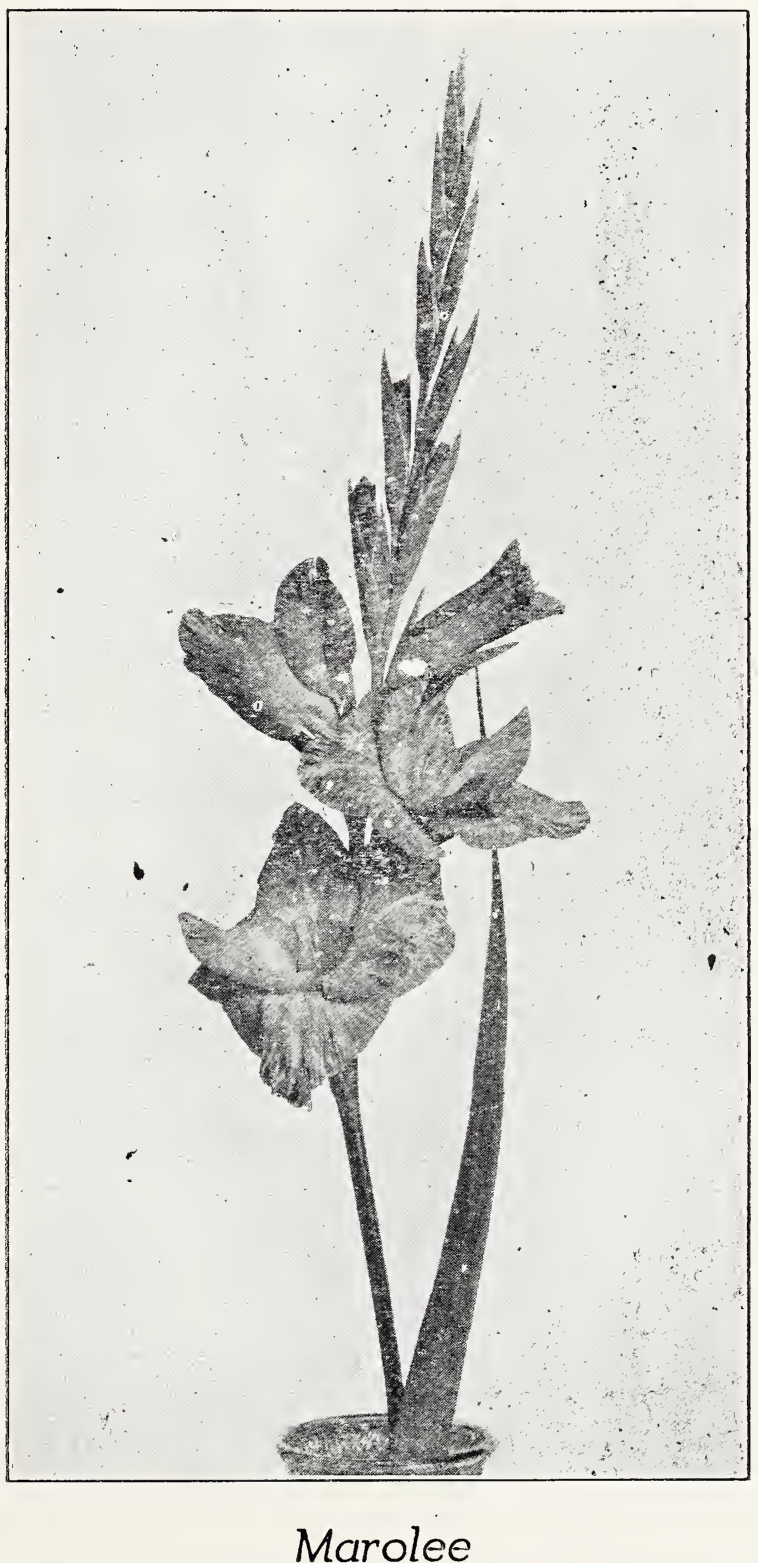




\section{Our Own Introductions}

\section{New this Year}

ANNIE MASON-A very large white with a small light yellow blotch in throat. Color is about the same as Jorges White and nearly as large, but this grows about 4 feet tall with a fine long spike of 18 to 20 buds, five open, placement good.

BONNIEBELLE-This is a very showy Glad. Color, Grenadine red with a light orange blotch on the three lower petals. Attracted much attention in our display at Toledo. Flowers well placed on fine spike.

ETHEL MAE-A good, strong-growing, cut flower varety, grows about ig, cut flower variety, grows about four feet tall. Flowers well placed with 8 open. Color: Hermosa pink, with a slight feathering of light jasper red.

FANNY CROSBY-One of the finest Glads we ever grew in our trial grounds. Color: Creamy white with a shade of light yellow in throat. It has a waxy texture like a lily. It has 18 to 20 buds on a fine straight spike, 8 opert. Wonderful substance, facing and spacing fine. Every spike that bloomed last season had several flowers with 8 to 12 petals. We are using this for a breeder, hoping some day to get a double Glad.

SANICE-Another extra fine Glad with a very peculiar color but one that shows up wonderfully well under artificial lights. Mr. Gersdorf described the color as follows: Pinkish buff to vinaceous lavender, shaded amaranth pink, and blotched amaranth purple. Bloom extra well placed on a good straight spike, 16 buds and 6 open, substance good.

RUFUS-This is a fine cut flower variety. Producing a strong healthy spike, bloom well placed with 5 open and a good propagator. Color: Rosa Doree with creamy white blotch on lower petals.
SEGRID STEIN-An extra early creamy white Glad with a small biotch of light yellow in throat and a purple line in center of lower petals. This blooms with us the same time as Elizabeth Tabor, Normanda, Lottie Belle, and Marolee, and makes a fine addition to our extra earlies. Good substance, well placed and spike always straight 14 to 16 buds and 7 open.

\section{Former Introductions}

ATALANTA, (Int. 1925)-Large open: flowers of Venetian pink, shading darker toward the tips. Faint central lines and feathering of deep rose pink. A very strong grower, extra propagator. This is so nearly like Bill's Priority that I have not been able to see any difference, only Atlanta with us was about one week earlier.

ELLA DAY, (Int. 1926)-Color La France pink with sulphur yellow blotch and a coral red feathering. This is a very large flower about six inches across and six open at once, a whole bouquet on a spike. Attracts much attention in our test plot. Several varieties that were introduced at a much higher price than this were hardly noticed when this was in bloom.

ELIZABETH ZANE, (Int. 1927)Dark scarlet with dark red blotch. Very ruffled and has a spike about four feet tall with sixteen to eighteen buds and four to five open at once.

EVA MARTIN, (Int. 1927)-A very ruffled and frilled flower that every one likes. Color: Outer portion of petals geranium pink, inner half picric yellow that fades to nearly white as the flower gets older. A very delicate colored Glad with about five or six flowers open at nnce.

FLOSSIE, (Int. 1925)-Color Rose Doree with feathering of Napal red in lower petals. This is a very strong grower and has a wonderful spike $4 \mathrm{r} / 2$ feet high with five large flowers out at once. 


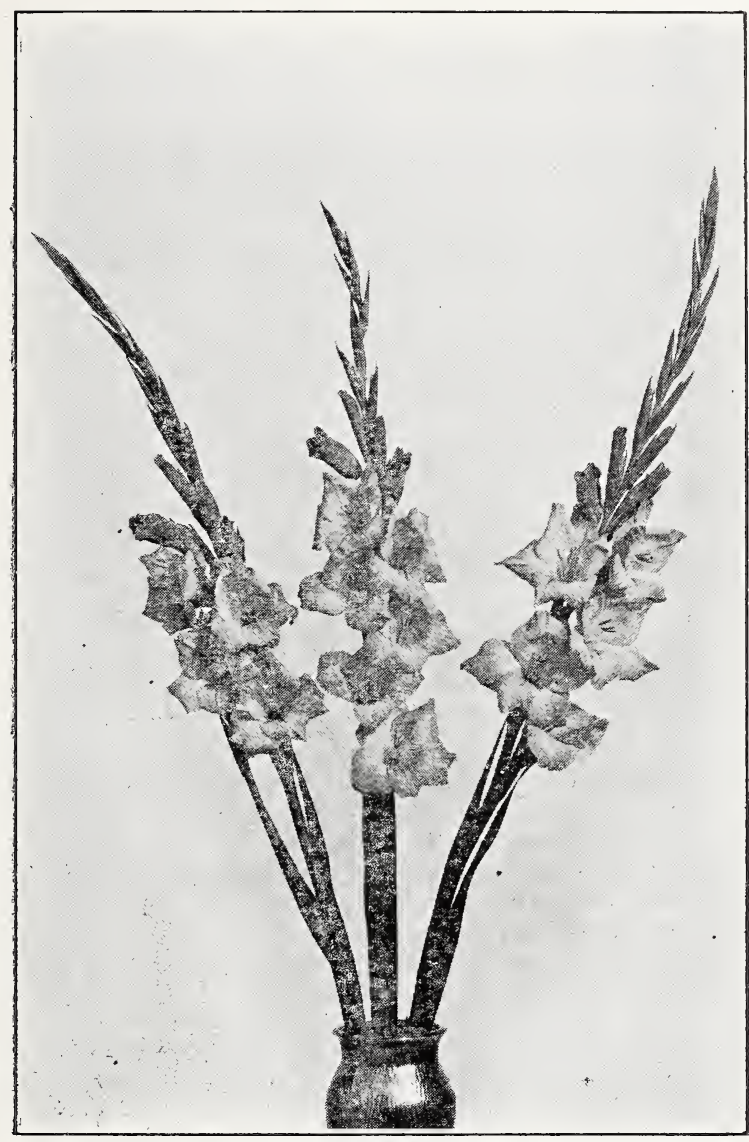

\section{Onilee}


LOIS MARY, (Int. 1926)-Color Jasper pink with sulphur yellow blotch on two of the lower petals. It has a very fine spike, four feet tall and five to six open. Increase good.

LOTTIE BELLE, (Int. 1925)-Color LaFrance pink, sulphur yellow blotcin with carmine red feathering. A good size flower well open on a fine long spike and very early, with us it blooms one week earlier than Elizabeth Tabor.

LYNDA DAY, (Int. 1925)-Color Primrose yellow, self color. This is a Prim, similar to Souvenir only differing some in shape and later. Very strong grower.

MAROLEE, (Int. 1927)-A very large flower that opens up very different from most Glads and attracts much attention because of its shape and color. Color is jasper pink with a buff yellow blotch and a tinge of scarlet around blotch and sometimes on edge of petals. See illustration.

NORMANDA, (Int. 1925)-Color Pittersweet orange shading to picr.c yellow in throat with a carmine feathering. Very strong grower about 4 feet high with us.

ONILEE, (Int. 1927)-Oriental pink with amber yellow blotch and slight daphne red feathering. Over twenty buds well placed on tall straight spike with six open. A fine cut flower variety and a good propagator.

ONEIDA JANE, (Int. 1926)-Color Geranium pink with white throat blotci and red feathering. This is a real cut flower, very early. Blooms a little before Elizabeth Tabor with us, is about four feet high. Sixteen to eighteen buds on spike with five or six onen. A seedling of Prince of Wales and a very fine early variety

SIRENE, (Int. 1925)-Color Begonia rose with streaks of scarlet red around the edge of petals and a white blotch in lower petals with a scarlet red feathering. Everyone likes this one.
WHITE PRINCE (Prim)-Originated by Geo. L. Werle of Warren, Pa., and catalogued here for the first time. We grew it in our trial plot last season and found it very good.

\section{MR. WERLE'S DESCRIPTION}

The best all round white prim I have ever seen, height, size of florets, placement, substance, willowy stalk, but does not crook, good producer of bulblets that grow, blooms well from small bulbs, color white, very small, subdued feather in one or two lower petals, a fine cut flower, opens up well for a prim, and does not fleck; or show pink. The florists like it, so will you.

Price each-large $\$ 1.00$; medium $75 \mathrm{c}$

\section{Commercial Varieties}

ALBANIA, (Kemp)-Pure silvery white, with edge of petals daintily ruffled. Faint pink markings on the tips of petals. An exceptional variety for every purpose.

ANNA EBERIUS, (Deiners)-Dark velvety purple, throat deeper shade. Large flowers well set on spike.

A. B. KUNDERD, (K)-Tall, large, intensely ruffled flower of delicate deep cream color, overspread finest blush pink. Entire lower petals beautiful primrose cream flushed pink at edges.

CATHERINA, (Velthuys) - Light grayish blue; lower petals a little cleeper in color and with a brownish red blotch. Tall spike and very pretty.

CAPTAIN BOYNTON, (Boynton)Tall straight plant, large, wide open flowers. Color: Lavender blue on white ground with purplish blotch on lower petals. Several open. Very strong grower. Good commercial variety.

CAMEO (Metzner)-Coral pink partially overlaid with darker color, large flowers, wonderful spike, many flowers out at once.

CRIMSON GLOW, (Betcher)-Rich, glowing crimson with a velvety center. Large flowers; early and vigorous. Popular and justly so. 


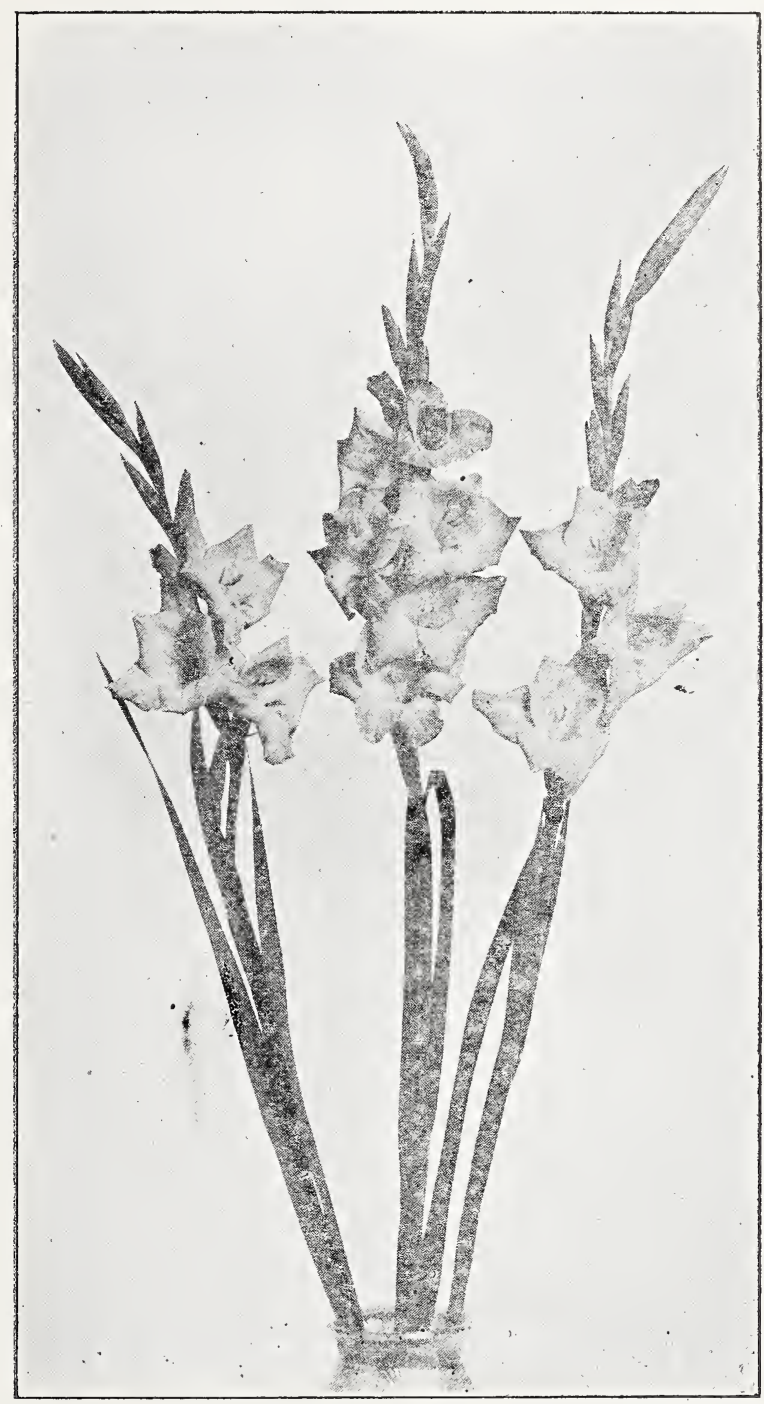

\section{Oneida Jane}


ELIZABETH TABOR-One of the new top-notchers. Large flowers of delicate rose pink, lower petals have brilliant crimson blotch which is tipped with soft yellow. Tall spike. In addition to these good qualities it is exceedingly early.

E. J. SHAYLOR, (K)-Tall, very strong plant and large bloom. A beautiful deep rose-pink, ruffled, very early and a good one.

EVELYN KIRTLAND, (Austin)-A wonderful shade of rose-pink, darker at the edges, fading to a shell-pink in the throat, the entire flower showing a sparkling luster. Many large flowers open at one time on a straight spike. It should be in every collection.

GIANT NYMPH, (J. C.)-Delicate salmon pink, slightly flaked with rose; throat blotched yellow with violet markings. Extra early.

GRETCHEN ZANG, (Austin)-Tall graceful spike of a beautiful, soft, pleasing shade of geranium pink, blending into scarlet on lower petals.

GOLDEN MEASURE (Kel.)-Conceded by many to be the finest golden yellow gladiolus. With the exception of a slight deepening of the color in the throat, it is self-color. Must be seen to be andreciated.

GOLDEN SWALLOW, (Austin)-A beautiful pure soft yellow variety and it has no throat marking of any kind. The ruffled blossoms are simply beautiful.

HERADA, (Austin)-Purest lavender mauve, deeper in the throat. Immense blooms of glistening luster.

HENRY FORD, (Deiners)-Large clear purple. Many open but in two rows that face in opposite directions. Nice for the garden but not so good commercially.

\section{JACOBA VAN BERJEREN-A} unique violet self-color on erect stem, many well arranged flowers open at a time. Highly recommended.

JACK LONDON (D) - Light salmon with vermillion stripes. Yellow throat with ruby stripes. Fine commercial variety.
JEWEL-Light salmon pink; large golden blotch. Very large open llowers on tall, slender spike.

LE MARECHAL FOCH-Pure, delicate, rose pink, wide open broad petals. Blooms the same time as Halley.

an exquisite shade of bright blue

LUCETTE, (Bill's) - As seen growing in the fields it appears to be absolutely pure white but back of petals carry a trace of phlox pink which imparts an alluring orchid sheen to the flowers. Lower petals also have a dainty subdued feather of wonderfully soft phlox pink. Very good as a commercial white.

LOUISE-Large, well opened flowers; lavender, with a wine-colored blotch in the throat.

MARIE KUNDARD (K)-Ruffled white with a very light lilac pink line in the center of the lower petal. Perhaps the best ruffled white Glad ever brought out.

MING TOY, (K)-Tall large beautiful buff, yellow throat. One of the very best Prims. Fine commercial varietv.

MRS. F. C. PETERS, (Fischer)Fine rosy lilac blossoms with softest crimson blotch; slightly ruffled and many open at one time; tall and vigorous. 'This is one of the very best lavenders.

MRS. FRANCIS KING-Long spike of immense flowers of light scarlet or flame red, shaded salmon. One of the older varieties. but it will be a long time before it is supplanted by any other red gladiolus.

MiR. MARK-A blue "glad". The flowers are light blue with a darker blotch in the throat.

ORANGE QUEEN (PFITZER)Fine orange yellow, deeper at end of petals. Orange red lines in throat. A beautiful Glad.

OPALESCENT, (Bill's)-Bill says: "They are wonderful spikes of very large rose lavender. A pure self color with soft lilac throat lines. Flowers are well placed with broad petals of good substance on strong, straight stalk. 
The Ashville Flower Fields

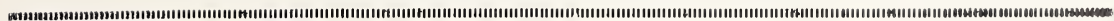

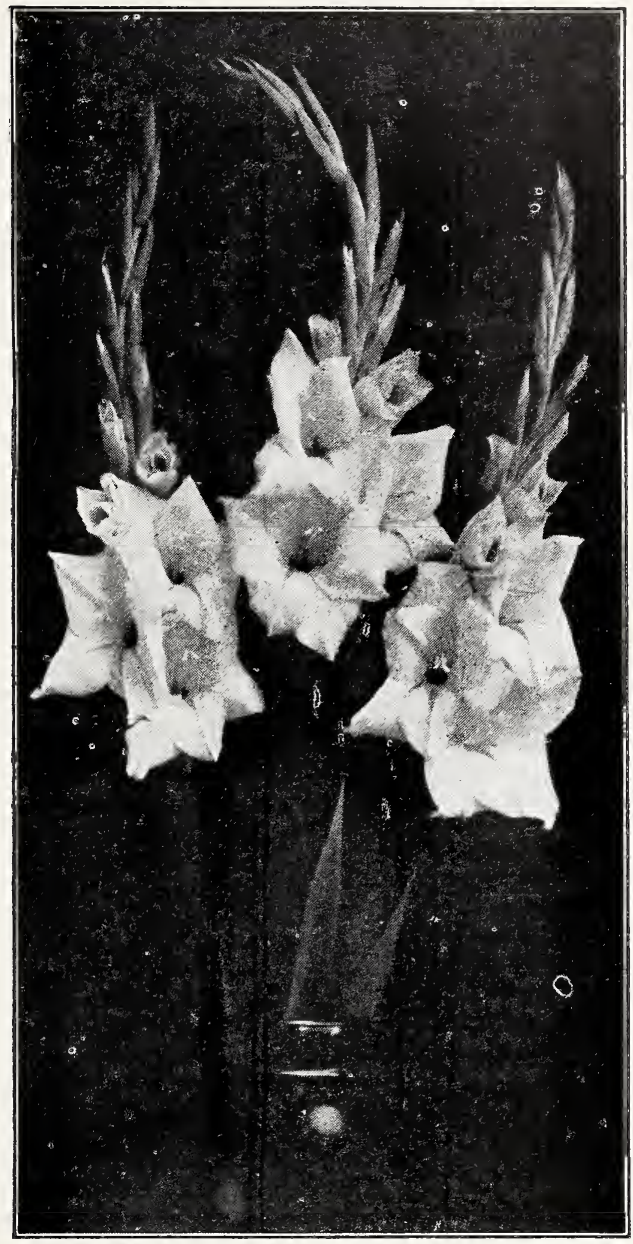

Opalescent [Bill's] 
PINK WONDER-Wondrously beautiful. The color is light pink with yellow shading at the base of lower petals, overlaid with a feathering of rose. Tall spikes with four or five massive, glistening blossoms open at one time.

PRINCE OF WALES-So'test saimon with an apricot undertone. Large flowers and very early. Beatstiful and deservedly popular.

PRIORITY (B.Il's) - -Large open flowers of venetian pink shading darker toward the tips. Faint central lines and feathering of deep rose pirk. Large and strong, yet delicate.

PRIM BEAUTY, (Christy)-Large blossoms of cream, heavily lined and pin strined with salmon, giving a color effect of rich salnın-buff.

PURPLE GLORY, (K)-Largest of the ruffled varieties. Color, deepest velvety maroon red, with almost black blotch, like burned into the petals; very unusual.

RICHARD DIENER, (Diener)-Pure geranium pink with a slight sprinkIing of ruby on creamy yellow center. Large ffaring blossoms on a tall spike.

ROSE ASH-One of the most popular flowers in our garden. The color is an exquisite old rose, blended with ashes of roses: one of the loveliest combinations of color; finely ruffled: tall straight spikes. A really magnificent flower.

ROMANCE (K)-Rose pink with all the petals edged steel blue. Tall spike with many large flowers open at one time. A very beautiful Glad.

SCARLANO (K)-Dazzling ruffled orange scarlet with almost black lines.

SCARLET WONDER, (Cowee)-Or Groff's Majestic. Plants four or five feet high, with broad, dark green foliage and compact truss of great rich velvety scarlet, fiery crimson flowers.

VANITY, (Bill's) - Delicate La France pink flushed over cream ground. Very tall, strong grower.
WHITE WONDER (Kemp)-A superb white with lilv-like flowers. tirnted lavender, which adds to its beauty; massive bloom on tall spike.

\section{Choice Varieties}

DR. F. E. BENNETT-Flowers of the largest size and of the most fiery red imaginable. Many open at one time and periectly placed on the stem.

GOLDEN THRILLS (K)-Heavily ruffled deep yellow. A feather of rose-pink adds materially to the beauty. One of the best yellow prims. Very fine.

GOLDEN DREAM (Groff)-Clear, deep yellow; tall and straight; a good number open. Its reflexing petals give if a beauty and distinction all its own.

GOLD EAGLE (A)-A pure golden yellow. Tall slender spike. Very prolific, often blooms from bulblets. Fine commercial yellow.

GLORIANA-Golden salmon with a clear yellow throat. Wonderful color; tall spikes. A really good Glad.

JOERG'S WHITE (Joerg) - A very large white variety. Five petals in each flower show no other color. The lower petal shades to a creamy yellow in the throat. A great exhibition flower.

LOS ANGELES-Immense spikes bearing huge blossoms of shrimp pink with a throat of orange tinted with carmine. A Pacific Coast sensation. The "cut and come again" "Glad."

LONGFELLOW (Prest)-Very tall spikes, La France pink. Wide open flowers. One of the best.

MR. W. H. PHIPPS-La France pink tinged with light rosy salmon; lower petals faintly striped and speckled with ruby. Enormous flowers on tall, stately spikes. A masterpiece.

MRS. LEON DOUGLAS-Enormous rose-colored blossoms striped with scarlet. Extra long spikes. This is probably one of the largest "Glads" in existence. Exceedingly beautiful. 


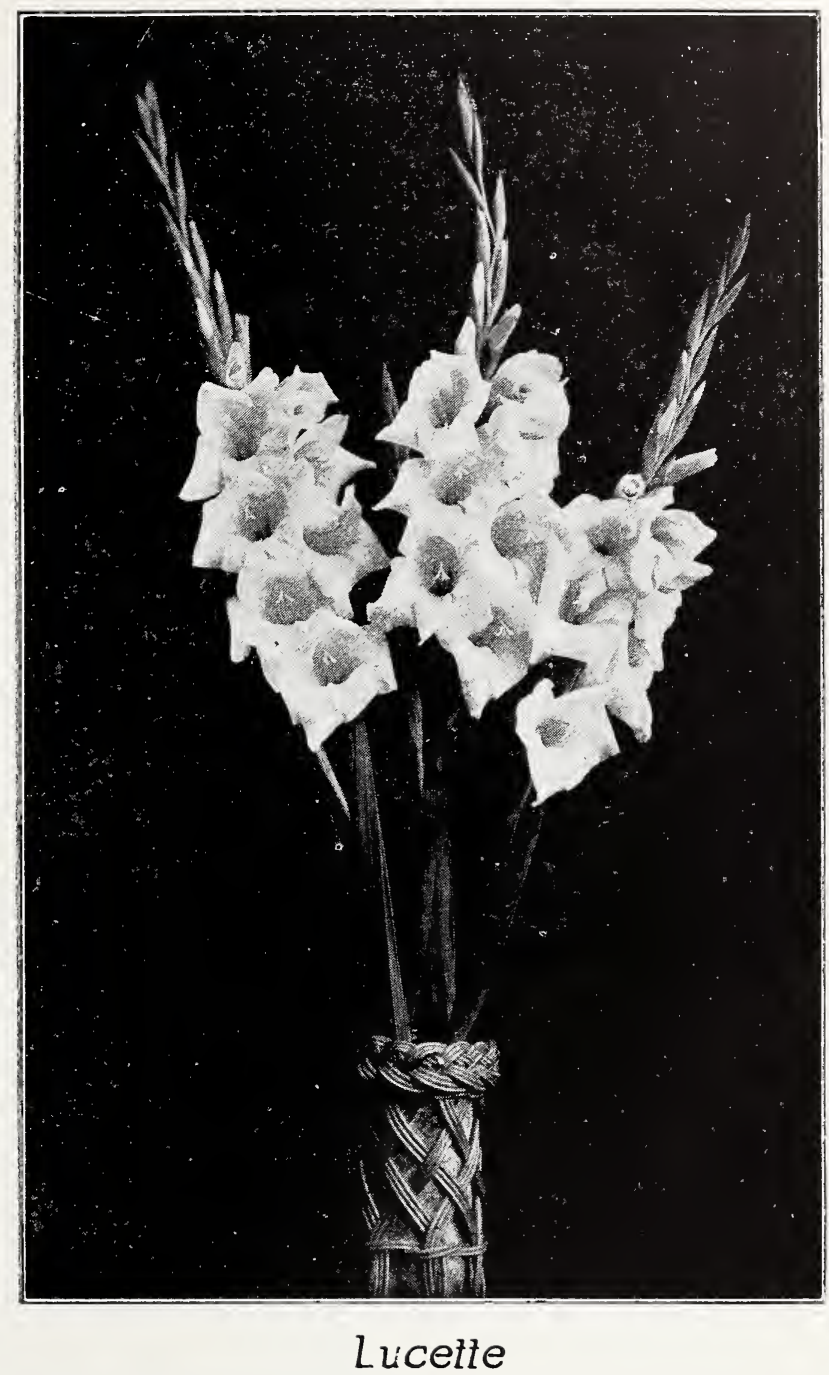


MRS. F. C. HORNBERGER (F.C.H.) A new pure white Gladiolus. This variety is nicely ruffled, with six or seven pure white flowers open at one time, keeping qualitv in water remarkable, where all buds open freely, and become waxy white. Superior to many introduced at a much higher price. Wonderful propagator and a very strong grower. Rated season of 1925. Commercial 96, Exhibition 93, by Gersdorff.

MRS. VAN KONYNENBURG (P). - Clear light blue, with slightly darker blotch. A very popular variety, and in great demand.

MARMORA (Errey Bros.)-This is a truly wonderful variety, and has created quite a sensation wherever shown. The color is a silvery lavender, with petunia-colored blotch. The blooms are exceptionally large, and are perfectly placed on splendid spikes showing up to fourteen flowers open at a time. Taking into account the remarkable color, perfect flower and spike and general allround quality, we consider this one of the most valuable varieties ever introduced.

MAURICE FULD (L. Merton Gage) -Large, well-expanded flowers or rich doree, with blotch of tyrian rose on pure white throat. Very striking.

PAUL PFITZER--Brilliant velvet purple, attractive new color, placement almost perfect, grows strong and healthy.

\section{PEARL OF CALIFORNIA (Kings-} ley).-A wonderfully large and fine new pink. A huge spike, with many open. A very outstanding pink.

PFITZER'S TRIUMPH. Probably the largest and best of known Glad on the market today. We think of it as a red, but in reality it is an orange salmon. Blooms wonderfully even from small bulbs.

QUINTON (Kemp)-Flowers are about 5 inches across, and of a pleas- ing hue of Coral Pink, suffused deep Tyrian Rose. Lower petal ivory yellow with faint Tyrian rose stripe. A splendid commercial variety.

\section{OTHER VARIETIES}

We have many varieties not listed here. If you do not find it, write us. we may have it.

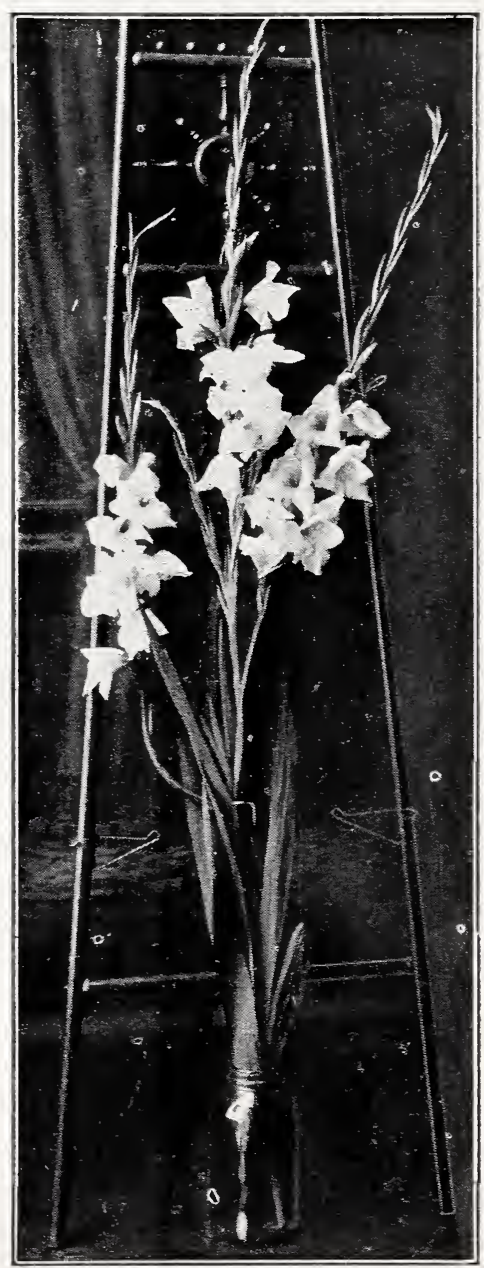

VANITY, (Bill's) 


\section{Price Lis'T \\ 1929}

\section{Carpenter's Originations, New This
Year}

\begin{tabular}{|c|c|c|}
\hline & & \\
\hline$N$ & AASON & $\$ 5.00$ \\
\hline $\mathrm{O}$ & $\mathrm{BE}$ & \\
\hline & MAE & \\
\hline & & \\
\hline & & \\
\hline GRII & STEIN & $\ldots 10$ \\
\hline
\end{tabular}

FORMER INTRODUCTIONS

\begin{tabular}{|c|c|c|}
\hline IT & .15 & .08 \\
\hline ELLA DAY & 5.00 & 3.00 \\
\hline ELIZABETH ZANE & .50 & .30 \\
\hline EVA MARTIN & 5.00 & 3.00 \\
\hline FLOSSIE & .35 & .20 \\
\hline TIE BELLE & .15 & .10 \\
\hline LOIS MARY & .20 & .12 \\
\hline LYNDA DAY & .10 & .07 \\
\hline MAROLEE & 7.50 & 5.00 \\
\hline MANDA & .15 & .10 \\
\hline DA JANE & 1.00 & \\
\hline & .50 & .30 \\
\hline & .50 & \\
\hline
\end{tabular}

COMMERCIAL VARIETIES

Nos. 1, 2 Nos. 3,4 Large $1 / 2$ size

ALBANIA $\$ .10$

ANNA EBERIUS

$\$ .06$

A. B. KUNDERD

.10

CATHERINA …………...... .10

CAPTAIN BOYNTON $\quad .15$

CAMEO (Metzner) ........... .10

CRIMSON GLOW …….... $\quad .08$

ELIZABETH TABOR $\quad .10$

E. J. SHAYLOR …….......

EVELYN KIRKLAND .07

GIANT NYMPH ……... .15

GRETCHEN ZANG …..... .07

GOLDEN MEASURE .... .12

FOLDEN SWALLOW $\quad .10$

HENRY FORD ............... .15

HARADA $\$ .07$

JACOB VAN

BERIEREN

IEWEL

LE MARECHAL FOCH $\quad .07$

ITCETTE

LOUISE

10

$\$ .05$

\begin{tabular}{|c|c|c|}
\hline MARIE KU & Large & $1 / 2 \mathrm{~s} 12$ \\
\hline MING TOY & .10 & \\
\hline IRS. F. C. PETERS & .15 & \\
\hline MRS. FRANCIS KING. & .07 & \\
\hline MK. MARK & .10 & \\
\hline PALESCEENT & .15 & \\
\hline ANGE QUEEN & .15 & \\
\hline CE OF WALES & .07 & \\
\hline TY & .10 & \\
\hline RITY ............ & .12 & \\
\hline BEAUTY & & \\
\hline LE GLORY & .20 & \\
\hline HARD DIENER & .15 & \\
\hline $\mathrm{E}$ ASH & .10 & \\
\hline ANCE & .10 & \\
\hline $\mathrm{K}$ WONDER & .10 & \\
\hline ARLENO & .10 & \\
\hline LET WO & .20 & \\
\hline & & \\
\hline
\end{tabular}

Twelve Bulbs for the Price of Ten

CHOICE VARIETIES

DR. F. E. BENNETT \$..25\$

GOLDEN FRILLS …......... $\quad .75 \$ .50$

GOLDEN DREAM ……..... $1.00 \quad .60$

GOLD EAGLE ……................ 1.00

GL.ORIANA ……………...... .50

JACK LONDON …………...... $\quad .10 \quad .06$

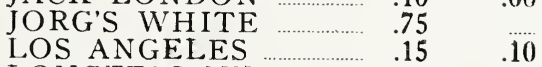

LONGFELLOW ………............ $\quad .40$

MAURICE FULD ………......50

MR. W. H. PHIPPA $\quad . .35 \quad .25$

MRS. LEON DOUGLAS $\quad . . . .10$

MRS. F. C. HORN-

BERGER ……… $1.25 \quad .75$

MRS. VAN KONYN-

ENBURG

PAUL PFITZER ……........ 1.00

PEARL OF CAII-

FORNIA 1.75

PFIT7ER'S TRIUMPH 1.75

IITNTON TRIUNPH .20

IIARMORA Bulblets-10 for $\$ 1.50$

For all cash orders of over five dollars taken from our regular retail price list (collections and snecials not included) we will give $30 \%$ extra value $n^{f}$ our originations and our selectinn. Wo vill also give extras with smaller orders. 
FOR $\$ 2.00$

Value

1 Box $\$ 1.00$ Special

$\$ 1.00$

6 Bulbs Crimson Glow, Red

.40

7 Bulbs Evelyn Kirkland, Pink

40

7 Bulbs Prince of Wales, Salmon .40

3 Bulbs Lynda Day, Yellow.......... . .25

3 Bubs Cathrena, Greyish Blue ... .25

\section{All for $\$ 2.00$}

$\$ 2.70$ $\therefore$

FOR $\$ 3.00=$

Vaive

50 Quality Mixture

1 . lossie, Rose 1 oree

6) Crinison Glow, Red

7 Lvelyn Kirkland, Pink

7 Prince of Wales, Salmon

6 Lynda Day, Yellow

6) Louise, Lavender

6) White Wonder, White

All for $\$ 3.00$

FOR $\$ 5.00:-$

Value

100 Quality Mixture

- Ilossie, Rosa Doree

$\$ 2.50$

3 Lottie Belle, Early Pink

3 Atalanta, Venetian Pink

3 Normanda, Pittersweet Orange

3 Lynda Day, Yellow.

3 Romance, Smoky Pink

3 Jewel, Light Salmon.

3 Louise, Lavender

3 Anna Eberius, Purple

3 White Wonder, White

3 Sirene, Begonia Rose.

\section{All for $\$ 5.00$}

$\$ 4.20$

\section{DOLLAR SPECIALS}

\section{Bulbs, Mixed $\$ 1.00$}

These will all be different, with wide range of color, and, if bought separately labeled, would cost over $\$ 2.00$.

Twenty different varieties. A fine mixture that has always been popular.

\section{Bulbs, Mixed, $\$ 1.00$}

An equal value of any variety in this catalog may be substituted at your request.

\section{QUALITY MIXTURE}

A high grade assortment made up mostly of named varieties which would cost nearly twice as much if purchased. separately. Can not fail to please the most exacting. Wide range of color.

\section{$\$ .40$ per Doz., $\$ 2.50$ per 100}

With all orders for this mixture we will include 3 bulbs of Flossie, value $\$ 1.00$, with each 100 .

\section{Extra for cash, retail only.}

Please do not send me orders for less than $\$ 1.00$.

A discount of $5 \%$ to all A. G. S. members. I am going to be generous in filling orders and will give extras. I am sure you will be pleased with the way your order is filled.

\section{PURE MAPLE SUGAR}

Do you want some real MAPLE SUGAR made from pure Maple Sap. Every spring in March and April we produce some. REAL QUALITY, too. Every bucket and spout is washed and scalded thoroughly, and when they are set to the trees every bucket has a cover to keep out dirt, rain, etc. Then we have the best evaporator we could get. Sanitary conditions and rapid process of evaporation are absolutely necessary to produce a fancy quality.

We make our sugar into $2 \mathrm{oz}$. cakes, 8 cakes fit in a fancy box.

Price $\$ .50$ per box, postage extra. Shipping weight $2 \mathrm{lbs}$.

Maple Syrup, $\$ 2.50$ ver Gal., postage extra. Shipping weight $18 \mathrm{lbs}$.

\section{WE THANK YOU}

We would be grateful to you if you would send us the names of your friends whom you know to be interested in Glads.

When you send in your order, just try it and see what you get for your trouble. 


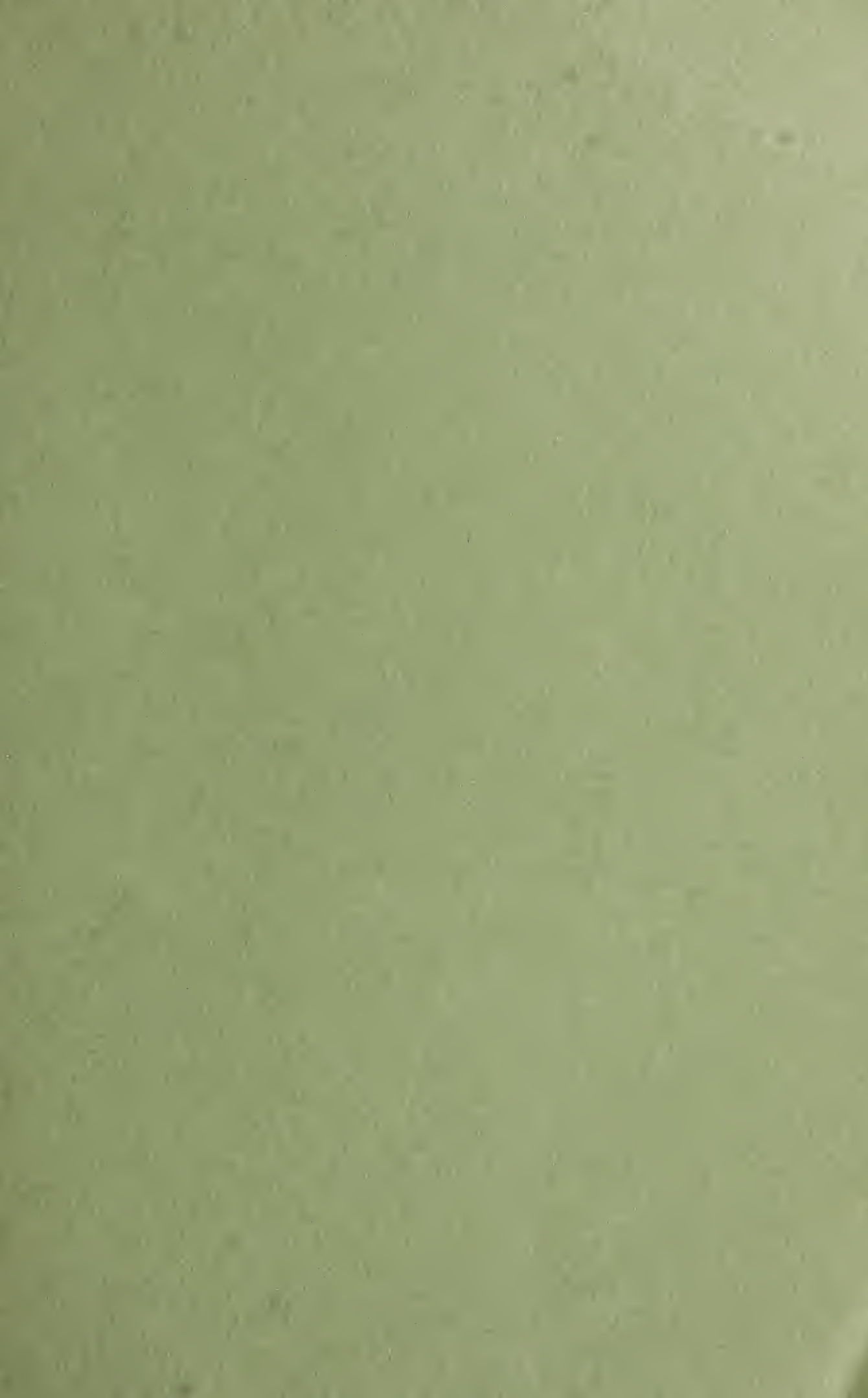


